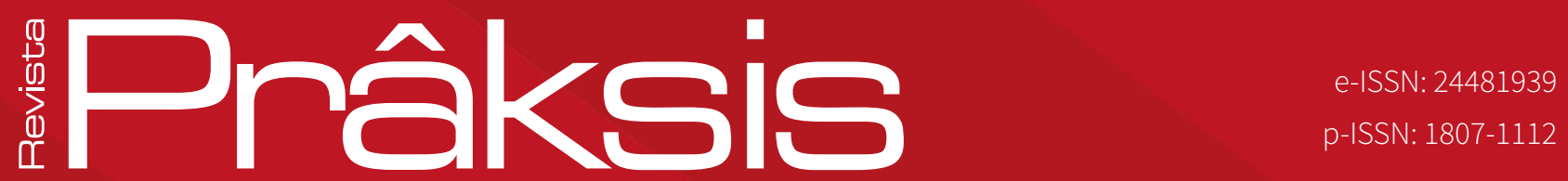

Recebido em: 03 de março de 2018

Aprovado em: 16 de junho de 2018

Sistema de Avaliação: Double Blind Review

RPR |a. 15 |n. 2 | p. 51-66|jul./dez. 2018

DOI: https://doi.org/10.25112/rpr.v2i0.1644

\title{
É UMA CASA PORTUGUESA \\ COM CERTEZA OU 0 \\ ESPLENDOR DE PORTUGAL
}

IT'S A PORTUGUESE HOUSE OF COURSE OR THE SPLENDOR OF PORTUGAL

\section{Gustavo Henrique Rückert}

Doutor em Literaturas Portuguesa e Luso-Africanas

(Universidade Federal do Rio Grande do Sul/Brasil).

Professor na Universidade Federal dos Vales do

Jequitinhonha e Mucuri (Teófilo Otoni/Minas Gerais).

E-mail: gh.ruckert@gmail.com. 


\section{RESUMO}

O esplendor de Portugal, romance publicado pelo escritor português António Lobo Antunes em 1997, representa o declínio da ação colonial portuguesa na África a partir do retrato de uma tradicional família de colonos em Angola no contexto do pós-independência e da guerra civil. A figura da casa da família, localizada em uma fazenda na Baixa do Cassanje, passa a ser o elemento fundamental para a compreensão das relações de poder decorrentes daquela sociedade. É a partir das memórias das vivências de quatro membros da família no local (Isilda, Carlos, Rui e Clarisse), que o colonialismo mistura-se à vida pessoal e passa a ser narrado a partir de suas fronteiras. Dessa forma, este artigo pretende investigar a figura da casa em $O$ esplendor de Portugal enquanto espaço de manifestação das relações coloniais estabelecidas nas margens do império português. Para a análise proposta, serão utilizados os estudos teóricos e críticos de diferentes autores, entre os quais destacam-se Homi Bhabha e Boaventura de Sousa Santos.

Palavras-chave: Casa. Colonialismo. Portugal.

\section{ABSTRACT}

The splendor of Portugal, a novel published by the Portuguese writer António Lobo Antunes in 1997, represents the decline of Portuguese colonial action in Africa, focusing on the portrait of a traditional settler family in Angola in the context of post-independence and civil war. The figure of the family house, located on a farm in the Baixa do Cassanje, becomes the fundamental element for the understanding of the relations of power deriving from that society. Colonialism mixes with personal life and begins to be narrated from its borders with the memories of the experiences of four members of the family in the place (Isilda, Carlos, Rui and Clarisse). Thus, this article intends to investigate the figure of the house in The splendor of Portugal as a space of manifestation of the colonial relations established on the margins of the Portuguese empire. The theoretical and critical studies of different authors, notably Homi Bhabha and Boaventura de Sousa Santos, will be used for the proposed analysis.

Keywords: House. Colonialism. Portugal. 


\title{
1 INTRODUÇÃo
}

\author{
É uma casa portuguesa, com certeza! \\ E, com certeza, uma casa portuguesa! \\ (Artur Vaz da Fonseca / Reinaldo Ferreira / Vasco Sequeira)
}

Diante dos versos que compõem a supracitada epígrafe, que ficaram popularmente reconhecidos na voz de Amália Rodrigues, o leitor pode vir a estranhar a persistência do nacional enquanto tema de debates acadêmicos nas áreas das ciências humanas. 0 globalizado mundo pós-moderno trouxe como uma de suas utopias a superação das fronteiras do estado-nação que caracterizaram a modernidade europeia. No entanto, em face dessa premissa utópica, ergue-se um presente cada vez mais distópico diante dos olhos espantados do mundo. $O$ agravamento dos conflitos no Oriente Médio e a precarização das condições de vida em inúmeros países africanos e caribenhos levam uma legião de sujeitos a marchar por refúgio nos países desenvolvidos ou em desenvolvimento. Como contrapartida, os discursos xenofóbicos entram novamente nas agendas dos principais líderes políticos europeus. Nos EUA, 0 presidente inacreditavelmente eleito Donald Trump vocifera contra imigrantes e idealiza a edificação de muralhas nas fronteiras do país. Fica claro, portanto, que as fronteiras fluidas da contemporaneidade têm motivação somente econômica. Como afirmou o escritor brasileiro Luís Ruffato, "as fronteiras caíram para as mercadorias, não para o trânsito das pessoas".1

De certa forma, podemos afirmar que os principais problemas de nosso tempo ainda dizem respeito às fronteiras identitárias impostas na modernidade, sejam elas nacionalidade, religiosidade, sexualidade ou classe social. Sendo essas fronteiras identitárias constituídas principalmente a partir da alteridade dos sujeitos colonizados, nosso presente ainda está absolutamente pautado pelas relações coloniais envolvendo os estados-nação europeus e aqueles surgidos de suas antigas colônias. Assim, a questão do nacional faz-se ainda extremamente necessária para compreendermos os problemas que nos assombram. Conforme refletira Tânia Franco Carvalhal (1997, p. 294), muito mais que abordar a questão do nacional é necessário colocar o nacional em questão, confrontando as narrativas que (des)constroem a nação. Nesse sentido, poucos autores foram tão longe quanto o escritor português António Lobo Antunes. Para a crítica literária Margarida Calafate Ribeiro (2004), Lobo Antunes traz em sua literatura aquilo que definiu como "epitáfio do império" - textos de sujeitos que tensionam a relação entre memória e narrativa a partir de suas traumáticas vivências nas margens do império português.

\footnotetext{
${ }_{1}^{1}$ Disponível em: < http://cultura.estadao.com.br/noticias/geral,leia-a-integra-do-discurso-de-luiz-ruffato-na-abertura-da-fei-
} ra-do-livro-de-frankfurt,1083463 >. Acesso em: 20 dez. 2015. 
Entre as numerosas obras do escritor que poderiam assumir a classificação de Calafate Ribeiro, destacamos $O$ esplendor de Portugal, romance publicado em 1997. O esplendor, ironicamente, aborda o declínio da ação colonial na África a partir de um retrato decadente, melancólico, solitário e fragmentado de uma tradicional família colonial em Angola no contexto do pós-independência e da guerra civil. Daí o fato de Calafate Ribeiro (2006, p. 54) afirmar que o romance aborda "os sinais de morte que pairam sobre a casa colonial".

A narrativa divide seu foco entre diferentes membros da família, que há gerações possui fazenda na Baixa do Cassanje. Assim, na primeira parte, narram Isilda e Carlos; na segunda, Isilda e Rui; e, na terceira, Isilda e Clarisse. Os três filhos, Carlos, Rui e Clarisse (nas palavras da avó, um mestiço, um epiléptico e uma prostituta), narram a partir de Lisboa no dia 24 de dezembro de 1995. Já a mãe, Isilda, permanece em Angola e de lá narra a partir de recortes temporais desde 24 de julho de 1978 até a mesma véspera de natal de 1995. Em comum, nas diferentes vozes que compõem o romance, está a memória do passado colonial. Dessa forma, os quatro narradores-personagens reconstituem de maneira traumática e fragmentada os episódios de suas vidas na casa colonial, que acaba por simbolizar o passado da família em Angola.

A problematização do passado por meio de memórias que atormentam os sujeitos situados às margens do antigo império português é característica marcante nos romances de Lobo Antunes. Para George Steiner, na entrevista denominada $O$ dia do encontro (2014), o escritor português é, ao lado de William Faulkner, referência na abordagem da dimensão temporal na narrativa: "você e Faulkner são ambos mestres do tempo, quando o tempo passado entra no tempo presente. 0 poderio terrífico das recordações históricas encontra-se em si e em Faulkner. Para mim vocês são mestres da reminiscência ativa". E é justamente o poderio terrífico das recordações mencionado pelo crítico que dá o tom de 0 esplendor de Portugal, como fantasma do passado que sempre volta a assombrar o presente da nação.

No campo teórico, Homi Bhabha (2013) é quem melhor aprofundou a questão dos tempos do estadonação moderno, em seu renomado ensaio "DissemiNação: o tempo, a narrativa e as margens da nação moderna". Para Bhabha, a nação é constituída, antes de mais nada, por narrações. As representações textuais dessas narrações, por sua vez, são marcadas pela ambivalência de um tempo disjuntivo, uma vez que cindido. Por um lado, há o tempo pedagógico - tempo que (re)monta um passado mítico e fundamenta o nacionalismo; por outro, há o tempo performático, presente dos sujeitos marcados pela cisão na pretensa unidade em torno do pedagógico. Dessa forma, a nacionalidade enquanto formação de uma pretensa homogeneidade identitária e cultural em meio à heterogeneidade social depende fundamentalmente do esquecimento para superar a cisão nos tempos da nação e celebrar o pedagógico. 
A narrativa daqueles sujeitos à margem da nação surge então como unheimlich que assombra o consciente nacional, trazendo à tona o estranho silenciado dentro de si.

Pensando no caso da identidade nacional portuguesa, pode-se dizer que seu tempo pedagógico está permeado pelos signos do messianismo e do expansionismo. Nesse sentido, a lenda da Batalha de Ourique é exemplar, uma vez que marca o estado em formação como escolhido por Deus para difusão de seu reino entre os homens. Assim, a expulsão dos mouros da Península Ibérica, em um primeiro momento, e a empreitada colonial na África, na América e na Ásia, em um segundo, ganham roupagens não só míticas como místicas. Daí o eterno retorno dos dois elementos mencionados, seja em Camões, Bandarra, Pessoa ou tantos outros nomes que se dedicaram à narrativa da nação.

Vale salientar ainda o que observa Patrick Chabal (1998) em relação à constituição das identidades nacionais europeias: elas se dão no momento da descoberta de novas alteridades com as grandes navegações. Desse modo, o ser português, enquanto sujeito representativo da grandiosa empreitada messiânica e expansionista que a pátria traz por missão em suas narrativas pedagógicas, passa pela negação dos sujeitos indígenas, negros e muçulmanos, nativos de suas mais variadas colônias. Na carta de Pero Vaz de Caminha (2013), o indígena brasileiro era descrito como o selvagem bom e ingênuo, que necessitava da salvação portuguesa. Em Os Lusíadas (2008), Camões descreveu os africanos como misteriosos, selvagens e ameaçadores, aproximando-os de personagens greco-romanos, como Adamastor e Polifemo. Jerónimo Corte-Real (1783), em sua epopeia sobre o naufrágio de Manoel de Sepúlveda, utiliza de mecanismos semelhantes aos de Camões, aproximando os africanos ora de referências clássicas, como Pan, ora de animais selvagens. Assim, no jogo de interidentidades (BOAVENTURA DE SOUSA SANTOS, 2010) instaurado pelo colonialismo português, narrar o outro como um selvagem (selvagem esse que é ora ameaçador ora ingênuo) serve para legitimar não só a empreitada colonial travestida de missão civilizatória, como também legitimar a própria identidade portuguesa enquanto povo civilizado, detentor da razão, da fé e da cultura. Como diria Edward Saïd (2007), a representação diz mais sobre quem representa do que sobre quem é representado. Daí a importância política desse poderoso instrumento que é a invenção de uma tradição (HOBSBAWN; RANGER, 1983) sobre a África pelas narrativas ocidentais.

Pensando-se a partir desse prisma, pode-se afirmar que o romance de Lobo Antunes trabalha justamente na cisão promovida pelos tempos da nação. De acordo com Bhabha (2013), as narrativas das margens (para o teórico indiano, o cotidiano de mulheres e colonizados) são quem melhor pode expor essa disjunção, por isso sempre ameaçam a frágil unidade nacional. No entanto, no romance em questão, a narrativa das margens é constituída a partir da voz de colonos portugueses em Angola. Esses sujeitos 
mais do que representar, materializam em si o próprio colonialismo português. Assim, Lobo Antunes explora com o recurso da ironia a fragilidade de seus discursos e de suas práticas, que ao pretenderem afirmar a identidade portuguesa frente à alteridade africana, acabam por conseguir apenas evidenciar o paradoxo entre seus tempos performático e pedagógico. 0 próprio título da obra, bem como o trecho do hino nacional que compõe a epígrafe, também são sintomáticos da sinalização irônica dessa ruptura, operada principalmente a partir do espaço da casa - sobre o qual nos debruçaremos para desenvolver a hipótese acima exposta.

\section{CORAÇÃO DA CASA}

A personagem Carlos, o primeiro a narrar, ao rememorar sua infância, lembra do processo de simbiose que acreditava acontecer entre seu coração e o relógio da sala - por sua vez entendido como o coração da casa colonial. Assim, convencia-se de que seus batimentos cardíacos eram responsáveis por manter vivo o elemento símbolo de sua família e da atuação colonial.

\footnotetext{
Durante muitos anos se me acontecia acordar antes dos outros pensava que o bater do relógio de parede na sala era o coração da casa e ficava horas e horas de olhos abertos quieto no escuro a ouvi-la viver na certeza de que enquanto o pêndulo dançasse de um lado para o outro

sístole diástole, sístole diástole, sístole diástole nenhum de nós morreria.

Durante muitos anos se me acontecia acordar antes dos outros pensava que o bater do relógio de parede na sala era o meu próprio coração e ficava horas e horas de olhos abertos quieto no escuro a ouvir-me viver (ANTUNES, 1999, p. 61).
}

Dessa forma, Carlos personificava em si toda a atuação colonial de sua família. A casa era o centro da fazenda na Baixa do Cassanje, representando em sua imponência o poderio colonial. Por isso, sentia-se responsável pela continuidade do colonialismo, que entendia sob os signos "família" e "casa": "a casa e a minha família e Angola inteira se sumiam, tinha de permanecer quieto, com qualquer coisa no peito da esquerda para a direita e da direita para a esquerda, deixando que houvesse a Baixa do Cassanje e o dia e o rio [...]" (Ibid., p. 62).

Já para Isilda, mãe de Carlos, a fantasia do filho não fazia sentido, uma vez que o coração da casa não pairava mais em sua família. Todos os sinais do tempo (esses sim o verdadeiro coração para ela) que pousavam sobre a fazenda, e sobretudo sobre a casa, desencadeavam o sentimento de culpa que tratava de oprimir em sua consciência, apoiada pelo pai:

O autêntico coração da casa eram as ervas sobre as campas ao fim da tarde ou no princípio da noite, dizendo palavras que eu entendia mal por medo de entender, não o 
vento, não as folhas, vozes que contavam uma história sem sentido de gente e bichos e assassínios e guerra como se segredassem sem parar a nossa culpa, nos acusassem, repetindo mentiras, que a minha família e a família antes da minha tinham chegado como salteadores e destruído a África, o meu pai aconselhava.

- Não ouças (Ibid., p. 74).

Já o pai de Isilda dizia que a casa era um simulacro de casa portuguesa, a fim de garantir aos colonos a capacidade de diferenciar-se social e racialmente dos africanos. Trata-se de um espaço sem coração, portanto. Assim, a casa como um símbolo decadente de status era uma forma de afirmação contra o que os portugueses chamavam cafrealização (BOAVENTURA DE SOUSA SANTOS, 2010), depreciação conferida aos colonos por viverem (ou terem vivido) na África.

Os brancos de Lisboa têm razão em troçar-nos, em olharem-nos como olham os pretos com a mesma indiferença ou o mesmo horror

explicava o meu pai

já que vivemos numa espécie de caricatura da vida deles em casas que lhes macaqueiam as casas por vergonha dos pobres os menos pobres dos pobres imitam os ricos não logrando senão assemelharem-se entre si sem se aproximarem do que queriam tornarse, os brancos de Lisboa (Ibid., p. 246).

Intimamente ligada à existência da família colonial, cercada de fantasmagóricas memórias capazes de alavancar o sentimento de culpa pelos crimes que esconde ou ainda uma bizarra cópia do poder lusitano e ocidental, a casa resistia ao tempo e representava a permanência de gerações portuguesas no local. É justamente no entrecruzar com o tempo que os espaços se tornam repletos de significação cultural (GUATARRI; ROLNIK, 1996).

Embora a discordância nas três visões sobre o coração (ou sua ausência) da casa colonial, para toda a família era uma propriedade que tinham por direito em terras africanas. Em um desabafo de Isilda ao ver sua propriedade ameaçada no pós-independência, fica bastante clara essa visão: "[...] nem o MPLA nem os cubanos têm o direito de me expulsar do que é meu, esta casa a quem faltam telhas, este aparador de que desaparecem pratos, estas cantoneiras sem garfos, estes armários de cabides roubados pelas tropas de passagem [...]" (ANTUNES, 1999, p. 57). Dessa forma, a casa acaba sendo representativa também de toda a África como propriedade do colonizador (destaque para o pronome possessivo meu utilizado por Isilda). O coração da casa, portanto, pode ser sintetizado como o próprio colonialismo português. Daí a sua importância como símbolo tão caro à família e, posteriormente, como conquista ao governo angolano. 


\title{
3 A FRAGILIDADE DOS ALICERCES ONDE SE ERGUE O DISCURSO RACIAL
}

Na narrativa conduzida pelos membros da família, um dos aspectos mais enfatizados é a questão racial. Entender os negros como sujeitos irracionais, propícios ao caos e próximos da selvageria, significa entender-se, enquanto branco, como sujeito necessário e capaz para o desenvolvimento local (simbolizado pela alta produtividade da fazenda).

Carlos, ao relembrar a infância, lembra de uma sensação de eternidade que sentia, que representava por sua vez a ideia de eternidade da própria atividade colonial:

\begin{abstract}
Não havia doenças, não havia mortes, a África, a minha casa, a minha família e eu não só éramos eternos como nada de mal nos aconteceria nunca [...], só os contratados é que cheiravam a cadáver e se sepultavam no cemitério do convento em redor do túmulo do colono onde as hienas uivavam, éramos eternos [...] (Ibid., p. 64).
\end{abstract}

No entanto, se seu mundo estava organizado de maneira binária, com a morte e a pobreza sendo tendência dos pretos, assim como a carapinha (lbid., p. 132), o entendimento de sua origem logo trata de confundir essa visão. Carlos era filho de Amadeu, o alcoólico marido de Isilda, que à época trabalhava em Cotonang, com uma jovem negra, que era empregada de um refeitório no local. Isilda acabou tomando a criança como filho e criando-a sem revelar sua origem.

Apesar de descrever-se com traços físicos brancos, Carlos é alvo de rejeição por parte de seus irmãos, Clarice e Rui, pela avó e pela mulher, Lena (a quem, por sua vez, também despreza por ser oriunda de um musseque). Em sua infância, sentia-se próximo apenas de Maria da Boa Morte, negra e empregada da família. Ela mesma acaba revelando ao menino o motivo de preferir a companhia dela e dos demais empregados à da família:

[...] descobri em mim no dia em que Maria da Boa Morte me disse na cozinha não me tratando por menino como aos meus irmãos, tratando-me por tu, [...] como se valesse o mesmo que eu, fosse minha igual

- Tu és preto (Ibid., p. 90).

A comparação valorativa ("como se valesse o mesmo que eu, fosse minha igual") surge quase que como desesperada afirmação de si enquanto branco no velho jogo de oposições com que via o mundo. Sua perturbação identitária é tão grande que não fica restrita à infância, uma vez que a expressão acima destacada é mencionada no tempo da narração (24 de dezembro de 1995), e não do narrado (década antes, durante sua infância). A resposta seguida da reflexão da criança indica essa perturbação, uma vez que seu status social não confirmava a identidade racial afirmada por Maria. 
- É verdade que sou preto?

Preto como a Josélia, o Fernando, o Damião, os contratados, o capataz ia chegar à cozinha e mandar-me trabalhar na safra, tiravam-se o quarto, os brinquedos, o meu lugar à mesa, comia pirão e peixe seco, bebia cerveja numa cantina, dormia numa esteira, curava icterícia com tubérculos, não acreditava em Deus, talvez no próximo Natal, como vivera uns anos por equívoco na fazenda, herdasse os calções usados do Rui [...] (Ibid., p. 92).

O fato de não conseguir situar-se na representação binária com a qual concebia o mundo, com os brancos colonizadores sendo detentores de privilégios e poderes, e os negros colonizados sendo vistos como objetos de trabalho sem valor humano, faz com que Carlos nunca se sinta inteiramente pertencente à sua família. Entre o ser branco e ser negro, representados pelo quarto dos privilégios e pela cozinha dos empregados, perturbava-se, sentindo-se sempre um estranho.

Chamavam um Carlos que era eu em elas não era eu nem era eu em eu, era um outro da mesma forma que se thes respondia não era eu quem respondia era o eu deles que falava, o eu em eu calava-se em mim e portanto sabiam apenas do Carlos delas, não sabiam de mim e eu permanecia um estranho, um eu que era dois, o deles e o meu, e o meu por ser meu não era, então dizia como eles diziam

Carlos (Ibid., p. 120).

O entre-lugar identitário de Carlos, presente no seu corpo e na sua compreensão da casa, é a marca de uma sociedade que construiu suas esferas de poder a partir de uma cama sexista e inter-racial. Para Boaventura de Sousa Santos (2010, p. 246), "a penetração sexual convertida em penetração territorial e interpenetração racial deu origem a significantes flutuantes". Esses significantes flutuantes sufragaram o racismo a partir da lógica do sexismo. Dessa forma, a chamada cama sexista e inter-racial, tão bem representada no caso da origem de Carlos, transformou-se em "unidade de base da administração do império" (Ibid.), que a partir do sexismo erguia o mito da democracia racial justamente para encobrir sua violência racial, mas também de gênero.

A definição que o pai de Isilda fazia do colonialismo português representa bem essa atitude, pois busca atenuar a violência racial a partir da flutuação dos significantes "branco" e "negro" na complexa estrutura de poder da sociedade colonial luso-angolana.

O meu pai costumava explicar que aquilo que tínhamos vindo procurar na África não era dinheiro nem poder mas pretos sem dinheiro e sem poder algum que nos dessem a ilusão do dinheiro e do poder que de fato ainda que o tivéssemos não tínhamos por não sermos mais que tolerados, aceitos com desprezo em Portugal, olhados como olhávamos os bailundos que trabalhavam para nós e portanto de certo modo éramos 
os pretos dos outros da mesma forma que os pretos possuíam os seus pretos e estes os seus pretos ainda em degraus sucessivos descendo ao fundo da miséria, aleijados, leprosos, escravos de escravos, cães (ANTUNES, 1999, p. 243).

\section{SOB O TETO DA VIOLÊNCIA}

Os alicerces do discurso racial que o colonialismo português erigiu na África acabaram por erguer uma casa que tem como teto (um teto opressor, diga-se de passagem) a violência. Todos os discursos e ações das personagens são tomados pelo ódio àquele que é diferente e deve, nessa visão, ser dominado, conforme o discurso do pai de Isilda. E na rede de poderes estabelecida pelo sistema colonial, aqueles mais suscetíveis a serem encobertos por esse teto de violência são sujeitos africanos, pobres e negros. Não raras vezes, são descritos por Isilda, em ato falho, como escravos de sua propriedade, e não como trabalhadores assalariados. Carlos explica como a condição de contratos da fazenda torna os sujeitos africanos vulneráveis aos desmandos de sua família: "havia quem suportasse a safra inteira, mas não podia ir embora a chocalhar o esqueleto porque com as despesas na cantina nos devia as vinte safras seguintes no caso de semear de graça e não comer" (Ibid., p. 17).

É por meio da exploração nas relações de trabalho, portanto, que esses sujeitos são objetificados pela família, configurando uma escravidão informal (pois disfarçada pelos contratos), porém legitimada pelo estado. A violência aos contratados tornou-se então banal e vista como necessária para garantir a produtividade:

[...] apesar de tantos cuidados os do planalto de Huambo, fornecidos pelo administrador a um saco de sementes por camponês, não se cansavam de morrer de amibiana mal chegavam em caminhonetes de gado, fingindo-se moídos da viagem para não trabalhar, desatavam logo com vômitos e febres, o administrador teimava que agonizavam de propósito, introduzia um cubo de gelo no ânus do soba para servir de exemplo (Ibid.).

Além de garantia da continuidade da produção local, a violência a esses sujeitos é naturalizada para garantir o divertimento sádico de Rui, filho de Isilda, que sofre de transtornos mentais. Suas brincadeiras preferidas na fazenda eram proporcionar sofrimento aos animais e aos empregados, algo que era aprovado pela mãe, que dizia que as pessoas não tinham senso de humor para apreciar as brincadeiras do menino.

Uma tarde ao regressar do rio com a espingarda de chumbinhos onde tinha estado a acertar nas lavadeiras, a vê-las pular, coçar-se, olhar para mim, fugir na direção da senzala largando os alguidares e o sabão, passei pelo armazém do girassol na mira de uma cabra que o cheiro das sementes atraísse, dei por um som de gargalhadas e luta 
nos sacos, girei a cancela a apontar a espingarda ao que pensava serem dois contratados roubando-nos a colheita para venderem às escondidas [...] (Ibid., p. 140).

A violência aos sujeitos negros é tão naturalizada nesse contexto que Rui chega a imaginar o irmão Carlos, visto por si como negro, como alvo de suas torturas: "eu que um dia destes sou grande, me chego a ele, o amarro a um tronco e lhe atravesso a língua com um prego" (Ibid., p. 184). Violência essa que era naturalizada não só por si, mas por toda a família, por meio de outras ações que visavam a agredir Carlos. A própria avó "encolhia-se toda se ele [Carlos] a beijava, cheirava-se enojada por cheirar a senzala, tirava a água-de-colônia da algibeira, não lhe oferecia presentes no Natal como à minha irmã e a mim, evitava-o, fingia não o ouvir" (Ibid., p. 145).

A partir da análise das representações romanescas da violência, fica claro, portanto, que a sociedade resultante de um colonialismo que se apoiou nos alicerces da violência racial (encoberta pela violência de gênero) para erigir um império de interidentidades, onde, como Carlos, os sujeitos acabam por flutuar nos entre-lugares identitários de colonizador e colonizado, branco e negro, português e africano, a violência torna-se teto comum ao cotidiano das organizações familiares. Dessa forma, os próprios núcleos das famílias são marcados pela violência das relações coloniais.

\section{A CAMA SEXISTA E INTER-RACIAL}

Conforme citado anteriormente, de acordo com Boaventura de Sousa Santos (2010), o colonialismo português construiu sua rede de poder e influências em suas sociedades híbridas a partir de uma cama sexista e inter-racial. A empreitada colonial, expressão máxima do expansionismo e do messianismo que marcam o tempo pedagógico da narração da identidade portuguesa, sempre foi vista enquanto aventura masculina. Não ao acaso, as mulheres em uma sociedade colonial, sobretudo aquelas pertencentes às sociedades locais, são vistas como objetos que estão de forma legítima e merecida ao dispor do homem conquistador de mares, de terras e de gentes. Não ao acaso, na literatura de viagem do século XVI, essa concepção já permeia o imaginário de seus autores. Pero Vaz de Caminha (2013), por exemplo, encantase com a nudez das indígenas brasileiras (que só pode ser entendida como nudez aos olhos europeus), e descreve de modo sensualizado a ação que seria banal das habitantes locais. Já Luís de Camões (2008), no canto X de Os Lusíadas, intitulado "Ilha dos amores", descreve uma ilha paradisíaca, habitada por ninfas, que recompensariam sexualmente Vasco da Gama e seus homens pelas aventuras anteriores. Assim, a mulher enquanto objeto para satisfação do desejo masculino compõe o imaginário viajante a respeito do "paraíso perdido".

Em $O$ esplendor de Portugal, a violência de gênero típica das sociedades constituídas a partir da colonização portuguesa é bastante evidente. A relação extraconjugal de Amadeu com a trabalhadora 
negra e menor de idade do refeitório de Cotanang torna explícita essa violência. Por sua vez, o fato de Isilda tomar para si o filho dessa relação de exploração do corpo feminino e africano, negando inclusive a possibilidade de maternidade à jovem, só confirma a desumanização imposta pela visão colonial, que reduz mulheres, negros e pobres à propriedade das elites locais.

A personagem Clarisse, filha de Isilda, também é bastante significativa da violência de gênero da sociedade colonial. Ao manter relações sexuais de forma descompromissada com diversos personagens, passa a ser taxada pela comunidade. Dessa forma, é como se sua posição social de mulher branca e portuguesa, pertencente à família detentora da fazenda, fosse invalidada pelo seu comportamento sexual. A violência com que sua sexualidade é condenada é tão estabelecida que mesmo sua avó reproduz o discurso que a condena sob o signo prostituta: "uma infeliz que há-de morar meio nua com as outras infelizes nas barracas da ilha a aquecer panelas na areia, a bater mandioca, a atender soldados" (ANTUNES, 1999, p. 217).

O discurso de violência da cama sexista e inter-racial imposto às mulheres da sociedade colonial é tão arraigado à estrutura de pensamento social que a própria mulher sobre quem ela incide, no caso Clarisse, acaba por abordá-lo para compreender-se no mundo. Quando já vive em Portugal e mantém um relacionamento com Luís Felipe, empresário casado, descreve-se para ele enquanto "tua", "puta" e "amante de senzala".

Sou a tua puta não sou podes confessar que não me zango a tua amante de senzala não tens de agradar-me te preocupares comigo ser terno quando foi do caroço no peito levaste sumiço porque só tens de pagar sou a tua puta obrigada a ter saúde que recebe dinheiro para ter saúde não para ser ingrata e adoecer podes confessar que não me zango de que serve zangar-me (Ibid., p. 331).

Assim, Clarisse acaba por assumir a condição imposta a si durante a sua adolescência em Angola, a de que sua identidade social e racial mudava conforme seu comportamento sexual, sendo então vista como mulher pobre e negra, e revelando que os corpos dessas mulheres seriam propriedade legítima dos homens brancos.

Outra personagem extremamente importante para a compreensão desse trânsito da identidade feminina articulada com a identidade social e racial na sociedade colonial é Isilda. Segundo suas próprias palavras, "sou mulher e me educaram para ser mulher, isto é para entender fingindo que não entendia" (Ibid., p. 102). No entanto, apesar de ser educada para não ter voz e participação plena nas decisões da casa colonial, o vício do alcoolismo de seu marido e seu posterior falecimento fazem com que tenha que assumir este papel administrativo, tradicionalmente legado ao homem: 
Me educaram para desculpar as mentiras e o desassossego deles, [...] desculpas conforme desculpei ao meu pai as suas infidelidades ruidosas e ao meu marido a sua indecisão patética, me ensinaram a inteligência de ser frívola com os meus filhos até a viuvez me obrigar a tomar conta deles e da fazenda na mesma impiedade com que tomava conta das criadas (lbid.).

Ao assumir a administração da fazenda, Isilda toma o lugar do patriarca. Não à toa, Maria Alzira Seixo (2002, p. 520) salienta que sendo "mulher, o ente tradicionalmente fraco, assume a força da terra da qual se apossa numa herança de intrusão". Dessa forma, Isilda assume também os privilégios que seriam reservados a homens brancos, portugueses e de alta posição social, sobretudo o controle da violência. Seus destratos com os contratados passam então a ser legitimados socialmente da mesma forma que suas relações sexuais, mesmo extraconjugais. Seu próprio marido, sabendo de seu caso com o comandante de polícia, não questiona ou reclama o adultério. A partir da comparação com a estigmatização que sofre sua filha Clarisse, fica claro que seu comportamento sexual é aceito por ocupar a posição masculina e colonizadora do patriarca da família colonial, o que só confirma a violência com que as relações sexuais, articuladas com as relações sociais e raciais, foram utilizadas para a construção e manutenção do império.

\section{A CASA TOMBADA E A PERSISTÊNCIA DAS RUÍNAS}

Com presente da narração que vai desde 1978, com Isilda, até 1995, com os quatro narradores, a obra toma como espaço de rememoração um império já em ruínas. Angola está independente e em guerra civil. Portugal não mais detém o poder político sobre o país. No entanto, fica evidente a permanência social do colonialismo. E é nesse ambiente em que o colonialismo ainda pauta as relações entre os sujeitos, seja em Portugal ou em Angola, que as personagens são assombradas por suas memórias. Dessa forma, há duas reações distintas frente à rememoração do período colonial. Isilda, velha, distante dos filhos e tendo sua fazenda tomada pelo MPLA, procura negar o presente e o passado em meio ao caos que toma conta de Luanda, onde se encontra. Já Carlos, Rui e Clarisse, em Lisboa e desunidos, procuram esquecer a qualquer custo o passado na África.

A busca pelo esquecimento de Isilda tem a ver com o par mérito/culpa a partir do qual olhava para a própria atuação colonial da família. Ao mesmo passo que via a casa colonial (e esta representativa de Angola) como propriedade particular a que tinha pleno direito ("o que me custou os olhos da cara e os olhos da cara da minha família, o meu gado, o meu café, o meu tabaco, as minhas máquinas, o meu dinheiro no banco" - ANTUNES, 1999, p. 276), também era assombrada pelo sentimento de culpa, que configurava para si o próprio coração da casa, conforme analisado anteriormente. Dessa maneira, chega 
ao fim de sua vida em delírio, na mesma véspera de natal a partir da qual narram os filhos, negando a realidade que viveu em Angola:

\begin{abstract}
A tropa do Governo e os estrangeiros da Unita nunca estiveram aqui, os bailundos nunca escaparam para a mata, nunca deixei os meus filhos no cais para Lisboa, nem um só cadáver nas ruas de Luanda, o meu marido, que história mais parva, nunca escondeu uma garrafa que fosse nas gavetas, não casei por estar grávida nem o meu pai me arranjou um noivo e lhe pagou para esconder a vergonha, sou virgem (Ibid., p. 373).
\end{abstract}

Em Lisboa, Carlos, sempre assombrado pela questão da identidade racial, procura esquecer a África como quem procura esquecer parte indesejável de si: "quero lá saber de Angola não me falem de Angola deixem-me em paz com Angola há séculos que Angola palavra de honra acabou para mim" (Ibid., p. 98). É importante ressaltar, inclusive, a reiteração da palavra "Angola", revelando o trauma e a angústia com o não esquecimento. Já Rui, internado por Carlos em uma casa de reclusão, reflete: "se me alimentar bem e não pensar em África ando fino" (Ibid., p. 144). A própria vivência no Cassanje, portanto, é vista como causadora de sua epilepsia, discurso reforçado por Carlos, que afirma que "se fosse por si, mandava-o de volta à África onde é tudo mais ao menos epiléptico" (Ibid., p. 190). Por fim, Clarisse também expressa necessidade de esquecer o local de sua infância e adolescência: "Há alturas felizmente em que me esqueço da África, da fazenda [...]" (Ibid., p. 285).

A partir do caótico retrato da família colonial, bem como de seus traumas culminando no ardente desejo de esquecer Angola, fica clara a intensidade da ruptura entre os tempos pedagógico e performático da nação e a consequente angústia identitária que essa cisão causa aos sujeitos. Se o tempo pedagógico narra um Portugal poderoso e protagonista, que se define a partir da própria identidade expansionista e messiânica, o colonialismo é o melhor retrato deste Portugal. No entanto, a narrativa memorialista do cotidiano dos indivíduos que de fato viveram às margens do império ressalta essa cisão, explorada ironicamente por Lobo Antunes.

0 esplendor de Portugal é a existência de suas colônias. Assim, a violência, a desordem e o subdesenvolvimento delas acabam por ser o maior retrato da "grandeza" desse Portugal do tempo pedagógico. Eis a grande ironia trazida à tona pelo autor. Por esse motivo, Maria Alzira Seixo (2002) considera $O$ esplendor o romance mais total e incisivo de Lobo Antunes sobre a identidade portuguesa e a ação colonial (dois elementos que não podem ser entendidos separadamente). Daí, apesar do desejo das personagens do romance, a impossibilidade de esquecer África - unheimlich que sempre se manifesta para assombrar a unidade identitária lusa. 


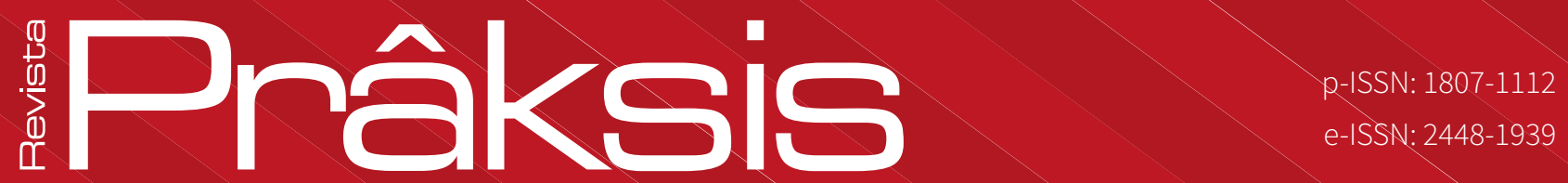

Ao rememorar a infância, Isilda reflete:

Pisávamos caramelos que era um castigo para arrancar da sola, mesmo depois de gastar horas com a faca o sapato colava-se ao chão e separava-se das tábuas numa dificuldade de estampilha, erguíamos o tornozelo, sentíamos um peso estranho, vinha o tapete atrás e era como se viesse a casa inteira, alicerces e tudo [...] (ANTUNES, 1999, p. 349).

A imagem trazida pela personagem é uma metáfora perfeita para entender a representação que a obra faz do colonialismo português a partir do espaço da casa. Assim, por mais que se busque romper com esse passado, ele está sempre presente, como casa que, mesmo em ruínas, tem seus alicerces erigidos sob os pés dos sujeitos portugueses ou angolanos. Essa casa, que abriga violência, abusos e culpa nas relações sociais, raciais e de gênero, tal qual um "problema hereditário" (Ibid., p. 23), está grudada com caramelo denso e de má qualidade nas "sombras do tempo" (Cf. Agamben, 2009). Por isso, mais que esquecê-la, devemos entendê-la para compreender os problemas contemporâneos referentes aos trânsitos identitários no sistema global, sobretudo nas relações entre os países centrais, periféricos e semiperiféricos.

\section{REFERÊNCIAS}

AGAMBEN, Giorgio. $\mathbf{O}$ que é contemporâneo? E outros ensaios. Trad. Vinícius Nikastro Honesko. Chapecó: Argos, 2009.

ANTUNES, António Lobo. 0 esplendor de Portugal. Rio de Janeiro: Rocco, 1999.

BHABHA, Homi. DissemiNação: o tempo, a narrativa e as margens da nação moderna. In.: 0 local da cultura. Trad. Myriam Ávila, Eliana Lourenço Reis e Gláucia Gonçalves. Belo Horizonte: Editora UFMG, 2013.

CAMINHA, Pero Vaz de. Carta de achamento do Brasil. In: CASTRO, Silvio. A carta de Pero Vaz de Caminha. Porto Alegre: L\&PM, 2013. p. 43-67.

CAMÕES, Luís de. Os Lusíadas. Porto Alegre: L\&PM, 2008. 
CARVALHAL, Tania Franco. A nação em questão: uma leitura comparatista. In: SCHMIDT, Rita Terezinha (Org.). Nações / narrações: nossas histórias e estórias. Porto Alegre: Associação Brasileira de Estudos Americanos, 1997, p. 293-301.

CHABAL, Patrick. What is Africa? Interpretations of post-colonialism and identity. In: ROSA, Victor Pereira da; CASTILLO, Susan (Org.). Pós-colonialismo e Identidade. Porto: Edições da Universidade Fernando Pessoa, 1998.

CORTE-REAL, Jerónimo. Naufrágio, e lastimoso sucesso da perdição de Manoel de Sousa Sepúlveda, e Leonor de Sá, sua mulher,e filhos, vindo da Îndia para este reino na nau chamada o galeão S. Joaõ, que se perdeu no Cabo de Boa-Esperança, na terra do Natal. E a peregrinação, que tiveram rodeando terras de cafres, mais de 300 léguas, até sua morte. Lisboa: Tipografia Rollandiana, 1783.

GUATTARI, Felix; ROLNIK, Suely. Micropolítica: cartografias do desejo. Petrópolis: Vozes, 1996.

HOBSBAWM, Eric; RANGER, Terence (Org.). The invention of tradition. Cambridge: Cambridge University Press, 1983.

O DIA DO ENCONTRO. Centro de Literaturas de Expressão Portuguesa da Universidade de Lisboa. 2014. 1:14:24. Disponível em: <https://www.youtube.com/watch?v=4krgSx7 TXxM>. Acesso em: 15 fev. 2015.

RIBEIRO, Margarida Calafate. As ruínas da casa portuguesa em Os cus de Judas e em 0 esplendor de Portugal. In: SANCHES, Manuela Ribeiro (Org.). Portugal não é um país pequeno: contar o império na pós-colonialidade. Lisboa: Edições Cotovia, 2006. p. 43-62.

Afrontamento, 2004.

SAID, Edward. Orientalismo: o Oriente como invenção do Ocidente. Trad. Rosaura Eichenberg. São Paulo: Companhia das Letras, 2007.

SANTOS, Boaventura de Sousa. Entre Próspero e Caliban: colonialismo, pós-colonialismo e interidentidade. In.: A gramática do tempo: por uma nova cultura política. São Paulo: Cortez Editora, 2010. p. 227-276.

SEIXO, Maria Alzira. Os romances de António Lobo Antunes: análise, interpretação, resumos e guiões de leitura. Lisboa: Dom Quixote, 2002. 